\title{
Vulnerability and Natural Disasters in Fiji, Papua New Guinea, Vanuatu and the Kyrgyz Republic
}

\author{
Raghbendra Jha \\ Australia South Asia Research Centre
}

January 2006

Correspondence to:

Raghbendra Jha

Australia South Asia research Centre,

Division of Economics,

RSPAS, Australian National University,

Canberra, ACT 0200, Australia

Telephone: 61261252683

Fax: 61261250443

Email: r.jha@anu.edu.au

\footnotetext{
* This study was funded by the Asia and Pacific Division of IFAD, under the overall guidance and support of T. Elhaut and G. Thapa. Thanks are due to Raghav Gaiha for helpful comments on an earlier draft. The views expressed here are however the personal views of the author.
} 


\begin{abstract}
This paper analyses vulnerability in Fiji, the Kyrgyz republic, Papua New Guinea and Vanuatu. In incorporating measures of vulnerability there is no major departure from the perspective of MDG 1 Analyses of vulnerability, like that in the present paper, emphasize the fact that the debates around poverty-growth elasticities are premised on the assumption of a state of world without any risks and uncertainties. In the real world in which the poor actually live they are subject to risks - both general and idiosyncratic - which affect their welfare. Thus poverty should not be viewed in static terms but within a framework that allows for changing states of the world. Nor should the possibility of reaching MDG1 be viewed simply as a matter of extrapolating from existing poverty levels using such computed growth poverty elasticities. Such a strategy runs the risk of becoming a statistical artefact with little relevance to the welfare of the poor.

This paper begins by briefly surveying the empirical literature on vulnerability. It makes a distinction between vulnerability measures based on household level data and measures based on aggregate data. Since household level data are not available for these countries this paper provides measures of vulnerability and quantifies certainty equivalent consumption growth for these countries over the recent past. It then projects from computed growth rates of consumption and their corresponding certainty equivalent magnitudes to understand some implications of such vulnerability for reaching the poverty related MDG (MDG1).

It is discovered that certainty equivalent consumption growth is much lower than average real per capita consumption growth indeed, in some cases, it is negative. This performance is linked to the incidence of aggregate shocks in these economies particularly in the 1990s. Based on these trends it is concluded that real consumption per capita by 2015 would be lower in all four countries than what is required to attain MDG1.
\end{abstract}

Keyword: Vulnerability, Certainty Equivalent Consumption, MDG1

JEL Classification: D18, D63, D80, D91, I32 


\section{Introduction}

In the extant literature either income or consumption expenditures as measured over short periods of time (say a year) have been regarded as proxies for the material wellbeing of households. However, economists have long recognised that a household's sense of well-being depends not just on its average income or expenditures, but also on the risks it faces as well. In particular, the concept of poverty should not be visualised in a static context but should permit changes in the states of nature and uncertainty of consumption outcomes. These alter the vulnerability of the household and affect its sense of well-being.

In this paper I briefly survey the empirical literature on vulnerability and provide estimates of vulnerability based on aggregate data for four countries - Fiji, Kyrgyz Republic, Papua New Guinea and Vanuatu. The plan of the paper is as follows. In section II I briefly survey the empirical literature on vulnerability. I make a distinction between measures based on household level data and measures based on aggregate data when household level data is not available. A measure of vulnerability based on such aggregate data is discussed in Section III. Section IV discusses results on vulnerability for these four countries. Section V projects from computed growth rates of consumption and their corresponding certainty equivalent magnitudes to understand some implications of such vulnerability for reaching the poverty related MDG (MDG1). Section VI concludes.

\section{Brief Overview of the Empirical Literature on Vulnerability}

The literature has distinguished between three forms of vulnerability (Hoddinott and Quisumbing 2003a, 2003b) - (i) vulnerability as expected poverty (VEP) or an ex 
ante measure of vulnerability; (ii) vulnerability as expected low utility (VEU) or an ex post measure of vulnerability; and (iii) Vulnerability as Uninsured Exposure to Risk (VER)

\section{$\underline{\text { VEP }}$}

VEP was first proposed by Chaudhuri et al. (2002). Vulnerability is here considered as the probability that a household will fall into poverty in the future. Thus we have:

$$
V_{i t}=\operatorname{Pr}\left(c_{i, t+1}=z\right)
$$

where $\mathrm{V}_{\mathrm{it}}$ is the vulnerability of household $i$ at time $t . \mathrm{c}_{\mathrm{i}, t+1}$ is this household's consumption at time $\mathrm{t}+1$ and $z$ is a poverty line. This is readily extended to the case where vulnerability rises with the length of the time horizon. Define $\mathrm{R}_{\mathrm{i}}(\mathrm{n}, \mathrm{z})$ as the probability of observing at least one spell of poverty for $\mathrm{n}$ periods and write:

$$
R_{i}(n, z)=1-\left[\left(1-\left(P\left(c_{i, t+1}\right)<z, \ldots,\left(1-P\left(c_{, t+n}\right)<z\right)\right)\right]\right.
$$

This methodology then uses I(.) as an indicator equalling 1 if the condition is true and zero otherwise and considers household to be vulnerable if risk in $n$ periods is greater than a threshold level of probability, $p$. Thus we have:

$V_{i}(p, n, z)=I\left\{R_{i t}(n, z)>p\right\}$

Empirically Chaudhuri et al. (2002) estimate ex ant vulnerability by modelling a household consumption function for cross section data:

$$
\ln c_{i}=X_{i} \beta+\varepsilon_{i}
$$

where $c_{i}$ is per capita consumption expenditure for the ith household, $\mathrm{X}_{\mathrm{i}}$ represents a bundle of observable household characteristics, $\beta$ is a vector of parameters and $\varepsilon_{\mathrm{i}}$ is a zero-mean disturbance term that captures idiosyncratic shocks that contribute to difference is per capita consumption levels. The variance of the error term is defined as: 
$\sigma_{\phi, i}^{2}=X_{i} \theta$

Estimation assumes that $c_{i}$ is normally distributed and estimates of $\beta$ and $\theta$ are obtained using a three-step feasible generalised least squares (FGLS) methodology. Using these estimated values the expected log consumption and the variance of the log consumption for each household as follows:

$\hat{E}\left[\ln c_{i} \mid X_{i}\right]=X_{i} \hat{\beta}$ and $\hat{V}\left[\ln c_{i} \mid X_{i}\right]=X_{i} \hat{\beta}$

The probability that a household will be poor in the future (say at at time $t+1$ ) is given by:

$$
\hat{v}=\hat{\operatorname{Pr}}\left(\ln c_{i}<\ln z \mid X_{i}\right)=\Phi\left[\frac{\ln z-X_{i} \hat{\beta}}{\sqrt{X_{i} \hat{\theta}}}\right]
$$

This can be estimated using cross section data. However it is sensitive to distributive assumptions both about the error term. Further the accuracy of the estimates depends upon whether the distribution of consumption across households given a set of characteristics at a given point in time is an accurate representation of the time-series variation of the consumption of the households.

\section{$\underline{\text { VEU }}$}

In this context Ligon and Schechter (2003) define the vulnerability of a typical household as the difference between the utility from a certainty equivalent consumption $\left(\mathrm{z}_{\mathrm{ce}}\right)$ sufficient to ensure that the household is not regarded as vulnerable and the expected value of the actual utility of the household from its (risky) stream of consumption. They then define vulnerability as the sum of three components: poverty (on average), aggregate risk and idiosyncratic risk). Minimization of vulnerability is then tantamount to maximizing expected utility. 
Consumption of a household $\mathrm{c}_{\mathrm{i}}$, has a distribution over different states of the world. Then vulnerability is defined as:

$\mathrm{V}_{\mathrm{i}}=\mathrm{U}_{\mathrm{h}}\left(\mathrm{z}_{\mathrm{ce}}\right)-\mathrm{EU}_{\mathrm{i}}\left(\mathrm{c}_{\mathrm{i}}\right)$

where $U_{h}$ is a weakly concave, strictly increasing function. This can be rewritten as: $\mathrm{V}_{\mathrm{i}}=\left[\mathrm{U}_{\mathrm{i}}\left(\mathrm{z}_{\mathrm{ce}}\right)-\mathrm{U}_{\mathrm{i}}\left(\mathrm{Ec}_{\mathrm{i}}\right)\right]+\left[\mathrm{U}_{\mathrm{i}}\left(\mathrm{Ec}_{\mathrm{i}}\right)-\mathrm{EU}_{\mathrm{i}}\left(\mathrm{c}_{\mathrm{i}}\right)\right]$. The first term is a measure of poverty - the difference between utility from $\mathrm{z}_{\mathrm{ce}}$ and actual consumption, $c$. The second term is a measure of the risk that the household faces. As Ligon and Schechter (2003) show this term can be split up into a measure of aggregate risk and a measure of idiosyncratic risk. Thus we cane write:

$V_{i}=\left[U_{i}\left(z_{c e}\right)-U\left(E c_{i}\right)\right]($ poverty $)$

$+\left\{U_{i}\left(E c_{i}\right)-E U_{i}\left[E\left(c_{i} \mid \bar{x}\right)\right]\right\}($ Aggregate risk $)$

$+\left\{E U_{i}\left[E\left(c_{i} \mid \bar{x}\right)\right]-E U_{i}\left(c_{i}\right)\right\}($ Idiosyncratic Risk)

\section{VER}

When risks are not managed effectively shocks result in drops in consumption and hence welfare losses. To this extent what matters is the uninsured exposure to risk. VER is an ex post measure of vulnerability. To get an estimable form of such vulnerability consider a household, $h$, living in village $v$ at time $t$. Let $\Delta \ln \mathrm{c}_{\mathrm{htv}}$ be the rate of growth of consumption per capita of this household between $t-1$ and $t$. We write $\mathrm{S}(\mathrm{i})_{\mathrm{tv}}$ as the aggregate shock and $\mathrm{S}(\mathrm{i})_{\mathrm{htv}}$ as the idiosyncratic shock. We also write $\mathrm{D}_{\mathrm{v}}$ as a set of binary variables identifying each village and $X$ as a vector of household characteristics. The equation to be estimated for VER can be written as:

$\Delta \ln c_{i t v}=\sum_{i} \lambda_{i} S_{i v}+\sum_{i} \beta_{i} S_{i t v}+\sum_{i} \delta\left(D_{v}\right)+\delta_{v} X_{i t v}+\Delta \varepsilon_{i t v}$

Of particular interest are the parameters $\lambda$ and $\beta$ as they capture the effects of aggregate and idiosyncratic shocks, respectively. 
Empirically as Gaiha and Imai (2004) argue, this can be more difficult than identifying a poor household. Vulnerability depends on the severity of shocks - both idiosyncratic as well as general. Typically households are better able to cope with idiosyncratic shocks as opposed to general shocks. Within the context of measurement poverty, as Gaiha and Imai argue, it is important to identify those households that become chronically poor as a result of such general shocks. This measurement necessarily involves the use of household level data. In this vein Gaiha and Imai (2006) assess the vulnerability of rural households in the semi-arid tropics of South India. They employ both ex ante and ex post measures of vulnerability and show that idiosyncratic risks account for the largest share (37\%), followed by poverty $(35 \%)$ and aggregate risks (22\%). Thus despite some risk sharing at the village level the rural population, particularly the landless, less educated, members of socially disadvantaged groups and small farmers, are vulnerable to idiosyncratic risks. Such risks force them to reduce consumption thus aggravating poverty and vulnerability.

\section{Measure of Vulnerability: The present paper's approach}

In the absence of household level data for the four countries studied in this paper Fiji, Kyrgyz republic, Papua New Guinea and Vanuatu - I use the approach of Auffret (2003). This paper provides a framework to compute vulnerability using aggregate data.

This methodology essentially involves computation of a rate of growth of consumption with no uncertainty that would give a representative consumer the same utility as the observed (uncertain) consumption growth. We equate the consumption of a representative individual with per capita consumption and assume that this 
(uncertain) aggregate per capita consumption follows a geometric Brownian motion with drift represented by $\frac{d c}{c}=\mu d t+\sigma d Z$ where $d Z$ is a standard Brownian motion with expectation and variance equal to 0 and $\mathrm{dt}$, respectively. The expected instantaneous per capita consumption growth is $\mu$ and $\sigma^{2}$ is the variance with $\sigma$ as the standard deviation. The standard deviation is often referred to as the volatility of real per capita consumption. Using Ito's Lemma, it can be shown that

$$
\begin{aligned}
& d(\log c)=\left(\mu-\frac{1}{2} \sigma^{2}\right) \cdot d t+\sigma \cdot d Z \text {. Hence } \\
& c_{t}=c_{0} \exp \left[\left(\mu-\frac{1}{2} \sigma^{2}\right)+\sigma[Z(t+1)-Z(t)]\right] \text { and } \\
& \log \left(\frac{c_{t+1}}{c_{t}}\right)=\left(\mu-\frac{1}{2} \sigma^{2}\right)+\sigma[Z(t+1)-Z(t)] . \text { Hence the variance of per capita }
\end{aligned}
$$

consumption growth and the expected instantaneous consumption growth are respectively given by $\sigma^{2}=\operatorname{var}\left[\log \left(\frac{c_{t+1}}{c_{t}}\right)\right]$ and

$\mu=E\left[\log \left(\frac{c_{t+1}}{c_{t}}\right)\right]+\frac{1}{2} \sigma^{2}$ where var and $E$ refer to unconditional variance and expectation. Auffret (2002) shows that this consumption process has the advantage of not violating the assumption of non-negative consumption and can be derived as the optimal outcome in a general equilibrium model with constant returns to scal technology defined by $\mathrm{dY} / \mathrm{K}=\mathrm{a} d \mathrm{~d}+\mathrm{s} d \mathrm{Z}$ where $K$ represents the stock of capital, $\mathrm{dY}$ is the instantaneous out[ut and the technological coefficients $\{\mathrm{a}, \mathrm{s}\}$ are exogenously specified constants with $\mathrm{s}>0$.

\section{Defining and Measuring Certainty-Equivalent Consumption Growth}

It is assumed that 
(i) Individuals have time-separable expected utility function with constant risk-aversion preferences given by $u(c)=\frac{c^{1-\rho}-1}{1-\rho}$ where $\rho>0$ and $\rho \neq 1$ is the coefficient of relative risk aversion or $u(c)=\log (c)$, the limiting case when $\rho=1$.

(ii) Per-capita consumption follows a geometric Brownian motion with drift represented by $\frac{d c}{c}=\mu d t+\sigma d Z$.

(iii) The rate of time preference is $\beta>0$.

Per-capita consumption at any time $t$ is given by $c_{t}=c_{0} \exp \left[\left(\mu-\frac{1}{2} \sigma^{2}\right)+\sigma[Z(t+1)-Z(t)]\right]$. Expected utility is $V\left(c_{0}, \mu, \sigma^{2}, \rho\right)=E_{0}\left[\int_{0}^{\infty} u(t) e^{-\beta t} d t\right]$ which can be rewritten as: $V\left(c, \mu, \sigma^{2}, \rho\right)=\frac{c_{0}{ }^{1-\rho}}{1-\rho} \frac{1}{\beta+(\rho-1)\left(\mu-\frac{1}{2} \rho \sigma^{2}\right)}-\frac{1}{\beta(1-\rho)}$

the same expected utility is obtained when per capita consumption follows the deterministic process represented by $\frac{d c}{c}=\left(\mu-\frac{1}{2} \rho \sigma^{2}\right) d t=\mu_{0}$ where $\mu_{0}=\mu-\frac{1}{2} \rho \sigma^{2} \cdot \mu_{0}$ is then defined as the certaintyequivalent consumption growth.

\section{Impact of Natural Disasters on Macroeconomic Aggregates in the Kyrgyz Republic, Fiji, Papua New Guinea and Vanuatu}


Following the logic that the volatility of consumption growth be identified as an indicator of vulnerability, Figures 1 to 4 (based on computations from WDI 2005) illustrate such volatility in these four countries.

Growth of Per Capita Real Consumption in Fiji

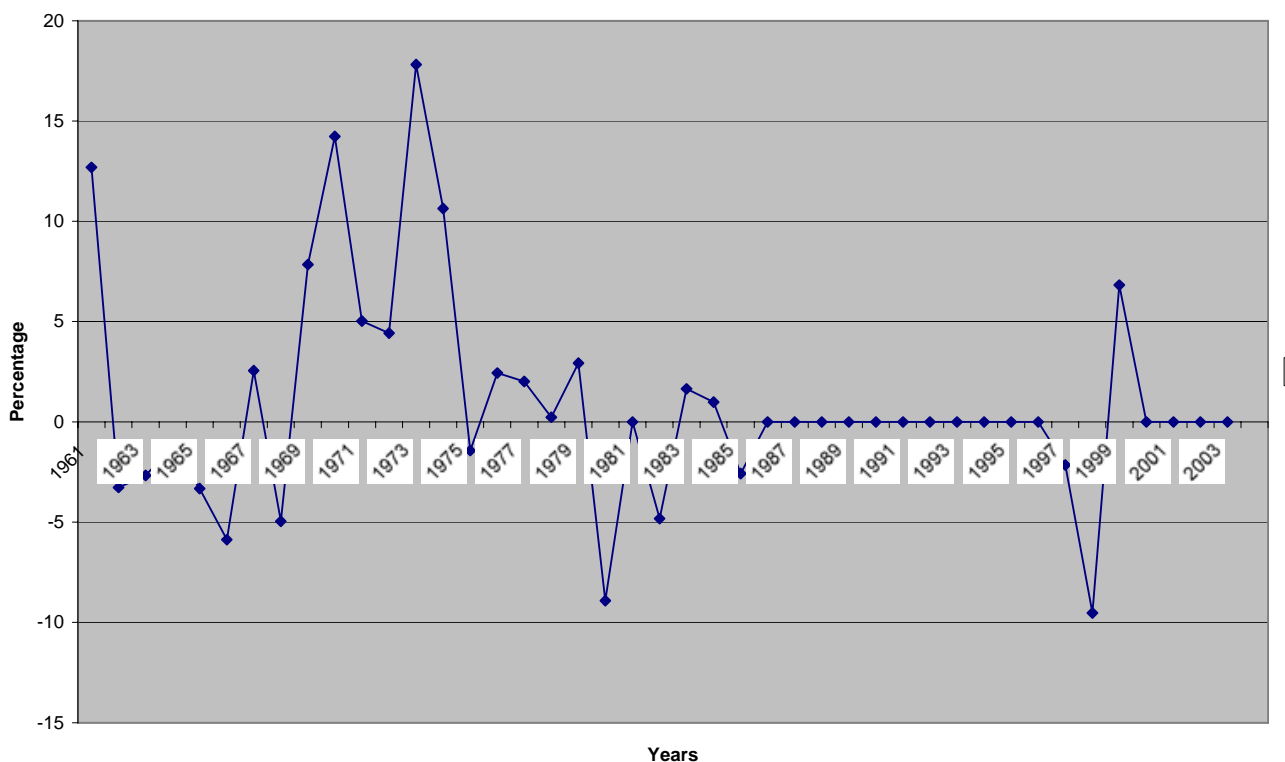

Figure 1

Growth of Per Capita Real Consumption in Kyrgyzstan

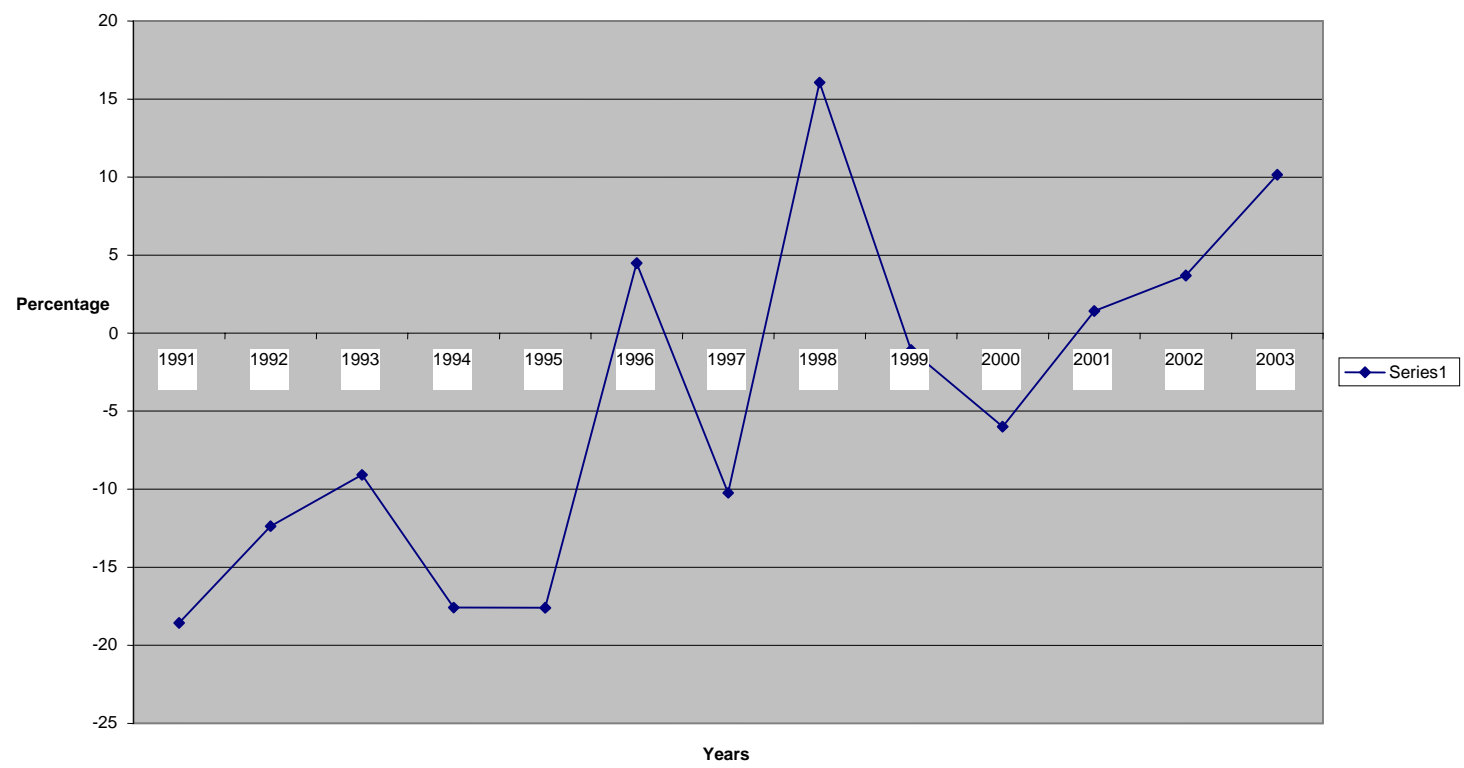


Figure 2

Growth of Per Capita Real Consumption in Papua New Guinea

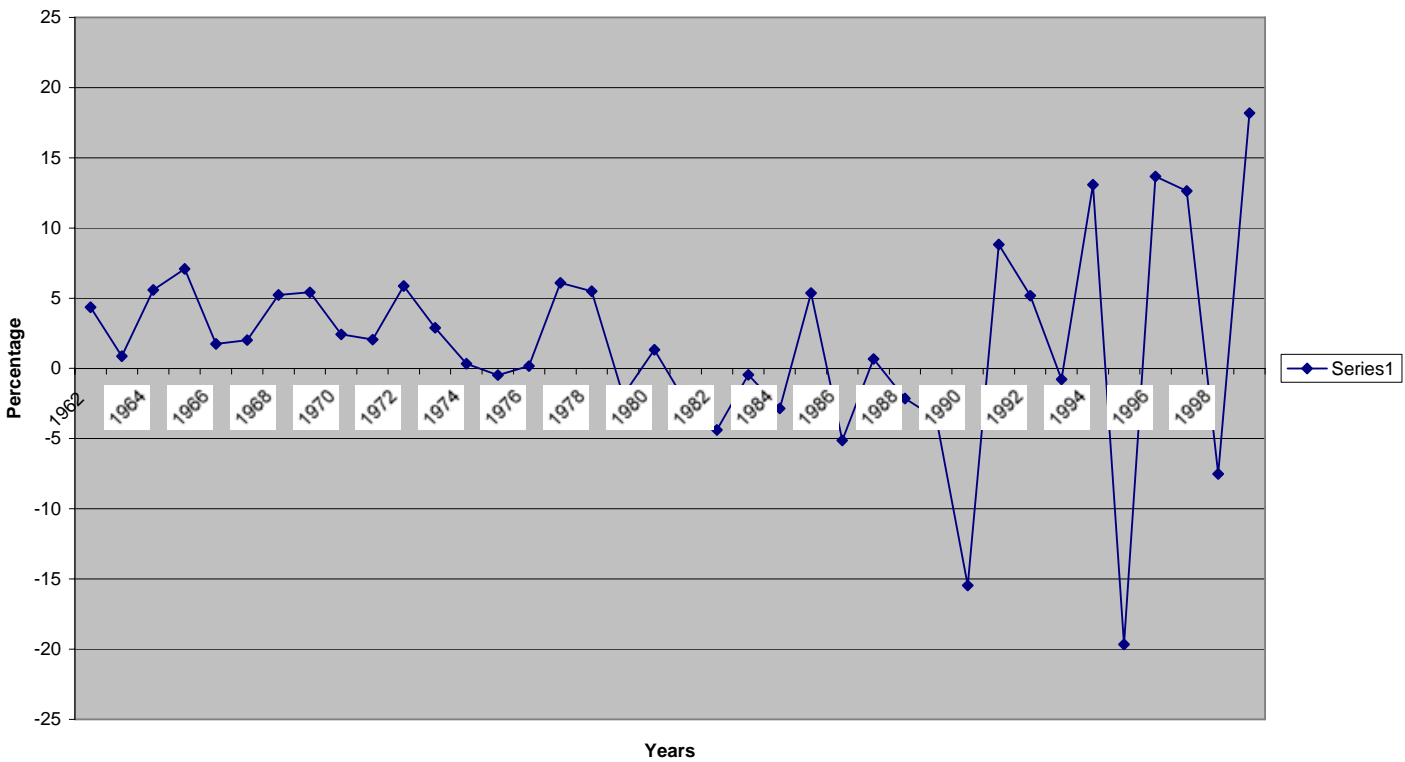

Figure 3

Growth of Per Capita Consumption in Vanuatu

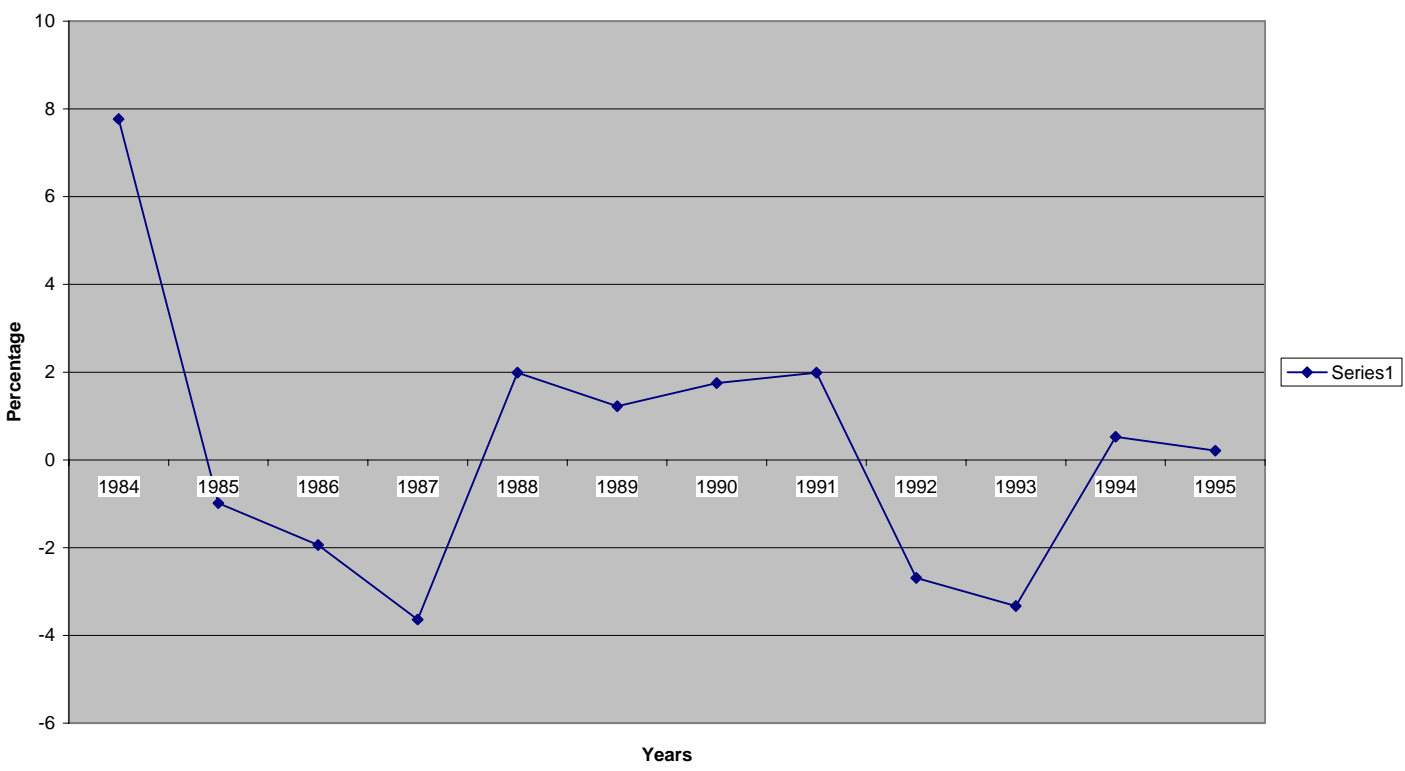

Figure 4 
Except for the Kyrgyz republic there done not appear to be a trend in per capita consumption growth in the 1990s in these countries. Even in the case of the Kyrgyz republic there is considerable volatility.

In Table 1 I report some basic data on the countries being studied in this paper.

Table 1: Some Basic Characteristics of the Countries being Studied

\begin{tabular}{|l|l|l|l|l|l|}
\hline Country & $\begin{array}{l}\text { Population } \\
\text { (mid 2003) } \\
\text { in millions }\end{array}$ & $\begin{array}{l}\text { GNI } \\
\text { per capita } \\
\text { (US \$) }\end{array}$ & $\begin{array}{l}\text { Average } \\
\text { annual growth } \\
\text { population } \\
(\%) 1997-03\end{array}$ & $\begin{array}{l}\text { Average } \\
\text { annual growth } \\
\text { labour force } \\
(\%) \text { 1997-03 }\end{array}$ & $\begin{array}{l}\text { Poverty } \\
\text { (\% below } \\
\text { national } \\
\text { poverty line) }\end{array}$ \\
\hline Fiji & $0.84^{*}$ & 2.240 & 1.1 & 2.4 & \\
$(1,855 ; 2,655)$ & $(1,070 ; 1,490)$ & $(1.0,0.9)$ & $1.2)$ & \\
\hline Kyrgyz & 5.1 & 340 & 1.1 & 2.2 & 48 \\
Republic & $(472 ; 2,312)$ & $(2,580 ; 440)$ & $(-0.1 ; 1.9)$ & $(0.5 ; 2.2)$ & \\
\hline Papua New & 5.5 & 500 & 2.4 & 2.6 & \\
Guinea & $(1,855 ; 2,312)$ & $(1,070 ; 440)$ & $(1.0 ; 1.9)$ & $(1.2 ; 2.2)$ & \\
\hline Vanuatu & 0.21 & 1,180 & 2.7 & N.A. & \\
& & $(1,070 ; 1,490)$ & $(1.0 ; 0.9)$ & $1.2)$ & \\
\hline
\end{tabular}

N.B. ${ }^{*}=$ in 2005

In the above table Fiji is being compared with east Asia and Pacific countries and with lower middle income countries. Thus whereas Fiji's GNI per capita was $\$ 2,240$ those of east Asia and the Pacific and lower middle income countries were, respectively, $\$ 1,070$ and $\$ 1490$. Similarly for the other column headings.

Kyrgyz republic is compared to Europe and central Asia and low income countries. Papua New Guinea is compared to east Asia and the Pacific and low-income countries whereas Vanuatu is compared to east Asia and the Pacific and lower middle income countries.

Source: WDI (2005)

Table 2 displays basic statistics on real per capita consumption growth in these countries (mean growth rate, standard deviation, skewness and kurtosis) along with the computed certainty equivalent growth rates. In the case of Fiji data are not available for the period 1985-95 hence two sets of results on growth rates are presented. Data on the Kyrgyz republic and Vanuatu are also scanty and Papua New Guinea does not report data for the period after 2000.

Table 2: Real Per Capita Consumption Statistics

\begin{tabular}{|c|c|c|c|c|c|}
\hline \multirow[b]{2}{*}{ Country (period) } & \multicolumn{4}{|c|}{ Real Per Capita Consumption (Constant LCU) } & Certainty \\
\hline & $\begin{array}{c}\text { Growth (\%) } \\
\mu\end{array}$ & $\begin{array}{c}\text { Standard } \\
\text { deviation } \times 100\end{array}$ & Skewness & Kurtosis & $\begin{array}{c}\text { Consumptiona } \\
\text { Growth }(\%) \\
\mu_{0}\end{array}$ \\
\hline
\end{tabular}




\begin{tabular}{|l|c|c|c|c|c|}
\hline Fiji (1960-85) & 1.857 & 6.597 & 0.839 & 0.34 & 0.986 \\
\hline Fiji (1997-99) & -1.61 & 8.19 & 0.29 & & -2.951 \\
\hline Kyrgyzstan (1990-2003) & -4.36 & 11.144 & 0.334 & -0.909 & -6.976 \\
\hline $\begin{array}{c}\text { Papua New Guinea } \\
\text { (1961-1999) }\end{array}$ & 1.8 & 7.176 & -0.57 & 2.04 & 0.770 \\
\hline $\begin{array}{c}\text { Vanuatu } \\
\text { (1983-1995) }\end{array}$ & 0.24 & 3.144 & 1.056 & 1.973 & 0.042 \\
\hline
\end{tabular}

Note: a: In line with Auffret (2003) I assume that $\rho=4$, which is consistent with empirical evidence. Source: Author's Computation based on data from WDI 2005.

Since we are not working with household level data no formal econometric analysis of the impact of natural disasters on poverty (along the lines of Gaiha and Imai 2006, for instance) is possible. However, suggestive evidence of the impact of such disasters on macroeconomic aggregates can be presented. A detailed breakdown of disasters in the four countries studied here appears in the Appendix. Juxtaposing these against the macroeconomic data from WDI leads to some insights into the impact of natural disasters. In the case of Fiji, for instance, a windstorm in March 1997 killed 25 people and caused \$27 million in damage. Further there was a drought in September 1998 affecting 263,455 people. Real per capita consumption growth fell from -2.15 per cent in 1997 to -9.52 per cent in 1998 . In the absence of a disaster there was a recovery in 1999. GDP per capita growth, which was 2.32 per cent in 1996 , fell to -1.74 per cent in 1997 recovering only to 0.409 per cent in 1998 . Again in the absence of a disaster in 1999 there was a sharp recovery in the GDP per capita growth.

In the case of the Kyrgyz republic major disasters in the 1990s included two earthquakes in 1992 that killed 58, affected 136,806 persons and caused more than $\$$ 161 million in damages, slides in 1994 that killed 51 and affected 58,500 persons, an epidemic in 1997 that killed 22 persons and affected 336, and an earthquake in 1997 that caused more than $\$ 2$ million in damages. As consequence consumption per 
capita growth was always negative during the 1990s except for the non disaster years of 1996 and 1998. Real per capita consumption growth was -18. 57 per cent in 1991, -12.37 per cent in $1992,-9.08$ per cent in $1993,-17.59$ per cent in 1994 and -17.6 in 1995 before recovering to 4.47 per cent in 1996 and sliding back to -10.23 in 1997 . Between 1991 and 1995 even real GDP per capita growth was negative. In later years even though GDP per capita growth became positive consumption growth remained negative underscoring the deleterious impact of disasters on consumption and, hence, poverty.

Major disasters in the 1990s in Papua New Guinea included slides in 1991 that killed 200 people, an earthquake in 1993 which killed 53 persons, affected 20, 2000 persons and caused more than $\$ 5$ million in damages, floods in 1992 and 1993 affecting more than 144,000 persons, a windstorm in 1993 that affected more than 40,000 persons, a volcano eruption in 1994 that affected more than 152,000 persons and caused $\$ 400$ million in damages, a drought in 1997 that killed 60 persons and affected 700,000 persons, an epidemic and a wave surge in 1998 that killed more than 2,300 persons and a flood in 1999 affecting more than 38,000 persons. Real per capita consumption growth was negative in 1990, 1993, 1995 and 1998. GDP per capita growth was negative in 1995, 1997, 1998.

In the case of Vanuatu major disasters in the 1990s included windstorms in 1992 and 1993 that killed 6 persons, affected more than 12,000 persons and caused more than $\$$ 6 million in damages, an earthquake in 1999 which killed 12 persons and affected more than 14,000 persons. Real consumption growth per capita figures are not available for Vanuatu for the post 1995 period but the impact of the disasters can be 
traced from the figures for the period 1990-95. In 1990 and 1991 this growth was positive at 1.75 and 1.99 per cent respectively and it fell sharply to -2.68 and -3.32 per cent respectively in 1992 and 1993. Growth of real per capita consumption was a very modest 0.52 per cent and 0.2 per cent in 1994 and 1995. GDP per capita growth fluctuated considerably from -2.54 per cent in 1990 to 10.17 in 1991 . It had a downward trend thereafter with growth rates of 1.95 per cent (in 1992), 3.21 per cent (in 1993), 6.64 per cent (in 1994), -2.25 per cent (in 1995), -0.14 per cent (in 1996), -1.11 per cent (in 1997), -0.88 per cent (in 1998) and -5.7 per cent (in 1999).

\section{Impact of Natural Disasters on the Possibility of Meeting the Poverty MDG}

With such impact of natural diasters on GDP and consumption growth it is reasonable to surmise that natural disasters may adversely affect prospects of attaining the millennium development goals (MDGs). In table 3 we extrapolate from existing average growth rates of per capita consumption as well as certainty equivalent growth rates to compute consumption levels in 2015 - the horizon for reaching the MDGs.

Table 3: Consumption Projections and Meeting the Poverty MDG

\begin{tabular}{|c|c|c|}
\hline \multicolumn{3}{|c|}{ Fiji } \\
\hline $\begin{array}{l}\text { Per capita real consumption } \\
\text { in } 1999 \text { (LCU) }\end{array}$ & $\begin{array}{l}\text { Per capita real consumption in } 2015 \text { at } \\
\text { average rate of growth of real } \\
\text { consumption between } 1997 \text { and } 1999\end{array}$ & $\begin{array}{l}\text { Per capita real consumption in } 2015 \text { at } \\
\text { certainty equivalent rate of growth between } \\
1997 \text { and } 1999\end{array}$ \\
\hline 1982.13 & 1531.28 & 1227.61 \\
\hline \multicolumn{3}{|c|}{ Kyrgyz Republic } \\
\hline $\begin{array}{l}\text { Per capita real consumption } \\
\text { in } 2003 \text { (LCU) }\end{array}$ & $\begin{array}{l}\text { Per capita real consumption in } 2015 \text { at } \\
\text { average rate of growth of real } \\
\text { consumption between } 1991 \text { and } 2003\end{array}$ & $\begin{array}{l}\text { Per capita real consumption in } 2015 \text { at } \\
\text { certainty equivalent rate of growth between } \\
1991 \text { and } 2003\end{array}$ \\
\hline 3093.06 & 2562.87 & 1221.05 \\
\hline \multicolumn{3}{|c|}{ Papua New Guinea } \\
\hline $\begin{array}{l}\text { Per capita real consumption } \\
\text { in } 1999 \text { (LCU) }\end{array}$ & $\begin{array}{l}\text { Per capita real consumption in } 2015 \text { at } \\
\text { average rate of growth of real } \\
\text { consumption between } 1962 \text { and } 1999\end{array}$ & $\begin{array}{l}\text { Per capita real consumption in } 2015 \text { at } \\
\text { certainty equivalent rate of growth between } \\
1962 \text { and } 1999\end{array}$ \\
\hline 466.65 & 620.8 & 521.74 \\
\hline \multicolumn{3}{|c|}{ Vanuatu } \\
\hline $\begin{array}{l}\text { Per capita real consumption } \\
\text { in } 1995 \text { (LCU) }\end{array}$ & $\begin{array}{l}\text { Per capita real consumption in } 2015 \text { at } \\
\text { average rate of growth of real } \\
\text { consumption between } 1984 \text { and } 1995\end{array}$ & $\begin{array}{l}\text { Per capita real consumption in } 2015 \text { at } \\
\text { certainty equivalent rate of growth between } \\
1984 \text { and } 1995\end{array}$ \\
\hline
\end{tabular}


Source: Author's Computation based on WDI (2005)

Thus over the horizon over the MDG have to be attained (2015) Fiji would experience $^{1}$ a net drop in per capita consumption of the order of magnitude 22.74 per cent (of its value in 1999) if consumption continued at the average pace set between 1997 and 1999. If certainty equivalent growth rates were used this drop would have been a staggering 38.06 per cent. In the case of Kyrgyz republic the drop between 2003 and 2015 would have been even 17.14 per cent if consumption continued at its average pace between 1991 and 2003 and 60.52 per cent at certainty equivalent growth rate. In the case of Papua New Guinea there would have been a rise in per capita consumption of 33.03 per cent in 2015 over its value in 1999 in case consumption grew at the average rate between 1962 and 1999 and a rise of 11.8 per cent in case consumption grew at the certainty equivalent rates. In Vanuatu per capita consumption would have grown by 2.67 per cent over the period 1995-2015) in case consumption per capita grew at its average rate over this period and a more modest 0.46 per cent if growth was only at the certainty equivalent rates. Thus, except for the case of Papua New Guinea, consumption growth in none of these countries would be anywhere near adequate to meet the MDG of halving poverty by 2015 . In fact, particularly if certainty equivalent measures were used, there could be rises in poverty. A major reason for this is the frequency of natural disasters that seem to be striking these counties.

\footnotetext{
${ }^{1}$ In the case of Fiji if 1960-1985 consumption figures were used there would have been a slight increase in consumption. However, both the average as well as the certainty equivalent growth rates are rather small. Because of the non-availability of data it was necessary to bifurcate the results for Fiji. I use figures from the latter period in the table above.
} 


\section{Conclusions and Agenda for Further Research}

A statistical measure of poverty based on consumption or income at different points of time ignores the fact that variability of its consumption has an impact on the utility of the household. If a utility interpretation were given to the standard measures of poverty it would have to be that such standard measures of poverty implicitly assume that the consumption stream is certain. It could be that a household that is regarded as having risen from below the poverty line to above it during any time period may actually have experienced considerable variations in consumption during this period, so that in terms of certainly equivalent consumption the household may still be below the poverty line. Assessing vulnerability is, therefore, fundamental to any assessment of human welfare and one that focuses only on observed consumption at a point in time without reference to the history of such consumption, is subject to the risk of misrepresenting vulnerability.

In incorporating measures of vulnerability there is no major departure from the perspective of MDG 1 Analyses of vulnerability, like the present one, emphasize the fact that the debates around poverty-growth elasticities are premised on the assumption of a state of world without any risks and uncertainties. In the real world in which the poor actually live they are subject to risks - both general and idiosyncratic - which affect their welfare. Thus poverty should not be viewed in static terms nor should the possibility of reaching MDG1 be viewed simply as a matter of extrapolating from existing poverty levels using such computed growth poverty elasticities. Such a strategy runs the risk of becoming a statistical artefact with little relevance to the welfare of the poor. Poverty should not be visualised in static terms but in a framework that allows for changing states of world. The present paper 
attempts such an analysis for the four countries studied and emphasizes the implications for MDG1 as well.

Since vulnerability has both distributional as well as level connotations it is best measured at the household level and, if possible, over time so that changes in factors affecting vulnerability over time may be identified. Furthermore, household level data can distinguish between aggregate as well as idiosyncratic shocks. However, when such household data are not available, it is standard to measure vulnerability by modelling the volatility of consumption growth and identifying a certainty equivalent consumption growth which would give the representative consumer a measure of utility equivalent to the observed volatile (and hence uncertain) stream. Since this measure uses aggregate consumption per capita neither distributional issues nor idiosyncratic shocks can be addressed.

This paper computes measures of the volatility of consumption growth and certainty equivalent consumption for Fiji, the Kyrgyz Republic, Papua New Guinea, and Vanuatu. It also records a brief history of aggregate shocks in these countries and surmises that the history of such shocks has led to fairly low and, in some cases, negative growth in certainty equivalent consumption. It is also suggested that unless measure are taken to ameliorate the impact of such shocks, it may be difficult to attain the poverty related MDG in these countries.

Further work in this area should involve the use of household level data to identify the impact of both aggregate as well as idiosyncratic shocks as well as to model the distribution of vulnerability across households in these countries. This would help identify the causes for such vulnerability and design better policies to address it. 


\section{References}

Auffret, P. (2003) 'High Consumption Volatility: The Impact of Natural Disasters?', Policy Research Working Paper 2962, The World Bank.

Auffret, P. (2002) 'The Importance of Financial and Insurance Market Integration in the Context of High Consumption Volatility in CGCED Countries', Washington, D.C.: The World Bank.

Chaudhuri, S., Jalan, J. and A. Suryahadi (2002) 'Assessing Household Vulnerability to Poverty from Cross Sectional Data: A Methodology and Estimates from Indonesia', Discussion Paper, Columbia University.

Gaiha, R. and K. Imai (2006) 'Vulnerability and Poverty in Rural India - Estimates for Rural South India' mimeo, IFAD, Rome.

Gaiha, R. and K. Imai (2004) 'Vulnerability, Persistence of Poverty and Shocks Estimates for Semi-Arid Rural India', Oxford Development Studies, 32(2):261-81.

Hoddinott, J. and A. Quisumbing (2003a) 'Data Sources for Microeconometric Risk and Vulnerability Assessments', Social Protection Discussion Paper Series No. 0323, The World Bank.

Hoddinott, J. and A. Quisumbing (2003b) 'Methods for Microeconometric Risk and Vulnerability Assessments', Social Protection Discussion Paper Series No. 0324, The World Bank.

Ligon, E. and L. Schechter (2003) 'Measuring Vulnerability', Economic Journal, 113(1):95-102. 


\section{Appendix:}

\section{Incidence of Disasters in Kyrgyz Republic, Fiji, Papua New Guinea and Vanuatu.}

The information on natural disasters presented here is taken from EM-DAT: The

OFDA/CRED International Disaster Database. In order for a disaster to be entered into the database at least one of the following criteria has to be fulfilled:

- 10 or more people reported killed

- 100 people reported affected

- a call for international assistance

- declaration of a state of emergency

Data on natural disasters is presented in three forms: Top 10, Summarized Table and Raw Data. Data on first two categories are reported here. 


\section{Appendix Table 1.1: \\ Country Profile for Natural Disasters: Fiji}

Top 10 Natural Disasters in Fiji sorted by numbers of people killed, total affected and economic damage costs

\begin{tabular}{|l|c|c|}
\hline Disaster & Date & Killed \\
\hline Wind Storm & 16-Feb-1931 & 200 \\
\hline Wind Storm & 9-Dec-1973 & 59 \\
\hline Wind Storm & 27-Mar-1979 & 53 \\
\hline Wind Storm & 17-Jan-1985 & 28 \\
\hline Wind Storm & 10-Mar-1997 & 25 \\
\hline Wind Storm & 28-Jan-1952 & 23 \\
\hline Wind Storm & 2-Jan-1993 & 21 \\
\hline Flood & 12-Apr-1986 & 19 \\
\hline Wind Storm & 24-Mar-1980 & 18 \\
\hline Wind Storm & 14-Jan-2003 & 17 \\
\hline
\end{tabular}

\begin{tabular}{|l|c|c|}
\hline Disaster & Date & Total Affected \\
\hline Drought & 4-Sep-1998 & 263,455 \\
\hline Flood & 12-Apr-1986 & 215,000 \\
\hline Wind Storm & 1-Mar-1983 & 200,014 \\
\hline Wind Storm & 2-Jan-1993 & 160,003 \\
\hline Wind Storm & 24-Oct-1972 & 120,000 \\
\hline Wind Storm & 17-Jan-1985 & 100,000 \\
\hline Wind Storm & 27-Mar-1979 & 35,900 \\
\hline Wind Storm & 24-Mar-1980 & 35,250 \\
\hline Drought & 1983 & 31,000 \\
\hline Wind Storm & 14-Jan-2003 & 30,000 \\
\hline
\end{tabular}

\begin{tabular}{|l|c|c|}
\hline Disaster & Date & Damage US\$ (000's) \\
\hline Wind Storm & 11-Dec-1992 & 261,313 \\
\hline Wind Storm & 2-Jan-1993 & 100,000 \\
\hline Wind Storm & 17-Jan-1985 & 73,000 \\
\hline Wind Storm & 1-Mar-1983 & 50,000 \\
\hline Drought & 1983 & 30,000 \\
\hline Wind Storm & 14-Jan-2003 & 30,000 \\
\hline Wind Storm & 10-Mar-1997 & 27,000 \\
\hline Wind Storm & Jan-1987 & 25,000 \\
\hline Wind Storm & 24-Oct-1972 & 22,500 \\
\hline Wind Storm & 28-Dec-1986 & 20,000 \\
\hline
\end{tabular}

Created on: 4 Jan 2006. - Data version: v06.01

Source: "EM-DAT: The OFDA/CRED International Disaster Database, www.em-dat.net - Université catholique de Louvain - Brussels - Belgium"

For some natural disasters (particularly floods and droughts) there is no exact day or month for the event, and for other disasters (particularly pre-1974) the available record of the disaster does not provide an exact day or month. 


\section{Appendix Table 1.2}

Summarized Table of Natural Disasters in Fiji from 1931 to 2005*

\begin{tabular}{|c|c|c|c|c|c|c|c|}
\hline & $\begin{array}{c}\text { \# of } \\
\text { Events }\end{array}$ & Killed & Injured & Homeless & Affected & $\begin{array}{r}\text { Total } \\
\text { Affected }\end{array}$ & $\begin{array}{r}\text { Damage US } \\
(000 \text { 's })\end{array}$ \\
\hline Drought & 2 & 0 & 0 & 0 & 294,455 & 294,455 & 30,000 \\
\hline ave. per event & & 0 & 0 & 0 & 147,228 & 147,228 & 15,000 \\
\hline Earthquake & 2 & 0 & 0 & 0 & 0 & 0 & 0 \\
\hline ave. per event & & 0 & 0 & 0 & 0 & 0 & 0 \\
\hline Flood & 6 & 34 & 0 & 10,000 & 223,600 & 233,600 & 16,500 \\
\hline ave. per event & & 6 & 0 & 1,667 & 37,267 & 38,933 & 2,750 \\
\hline Wind Storm & 28 & 500 & 1,367 & 36,772 & 745,451 & 783,590 & 632,135 \\
\hline ave. per event & & 18 & 49 & 1,313 & 26,623 & 27,985 & 22,576 \\
\hline
\end{tabular}

Created on: 4 Jan 2006. - Data version: v06.01

Source:"EM-DAT: The OFDA/CRED International Disaster Database, www.em-dat.net - Université catholique de Louvain - Brussels - Belgium"

*Events recorded in the CRED EM-DAT. First Event: Feb/1931, Last Entry: Sep/2005.

*Epidemics included 


\section{Appendix Table 2.1}

\section{Country Profile for Natural Disasters: Kyrgyzstan}

N.B. Kyrgyzstan independence August 1991, prior to that all natural disasters in that area included in Soviet Union.

Top 10 Natural Disasters in Kyrgyzstan sorted by numbers of people killed, total affected and economic damage costs

\begin{tabular}{|l|c|c|}
\hline Disaster & Date & Killed \\
\hline Slides & 14-Apr-1994 & 111 \\
\hline Earthquake & 19-Aug-1992 & 54 \\
\hline Slides & 9-Mar-1994 & 51 \\
\hline Slides & 20-Apr-2003 & 38 \\
\hline Slides & 26-Apr-2004 & 33 \\
\hline Epidemic & 13-Mar-1997 & 22 \\
\hline Extreme Temperature & 16-Oct-2000 & 11 \\
\hline Slides & 5-Aug-2004 & 11 \\
\hline Slides & 17-Apr-2004 & 5 \\
\hline Earthquake & 22-May-1992 & 4 \\
\hline
\end{tabular}

\begin{tabular}{|l|c|c|}
\hline Disaster & Date & Total Affected \\
\hline Earthquake & 19-Aug-1992 & 86,806 \\
\hline Slides & 14-Apr-1994 & 58,500 \\
\hline Earthquake & 22-May-1992 & 50,000 \\
\hline Flood & 18-May-1998 & 7,728 \\
\hline Flood & 10-Jun-2005 & 2,050 \\
\hline Earthquake & 9-Jan-1997 & 1,230 \\
\hline Slides & May-2002 & 1,002 \\
\hline Epidemic & 13-Mar-1997 & 336 \\
\hline Slides & 20-Apr-2003 & 211 \\
\hline Slides & 26-Apr-2004 & 96 \\
\hline
\end{tabular}

\begin{tabular}{|l|c|c|}
\hline Disaster & Date & Damage US\$ (000's) \\
\hline Earthquake & 19-Aug-1992 & 130,000 \\
\hline Slides & 14-Apr-1994 & 36,000 \\
\hline Earthquake & 22-May-1992 & 31,000 \\
\hline Flood & 10-Jun-2005 & 2,660 \\
\hline Earthquake & 9-Jan-1997 & 2,000 \\
\hline Slides & May-2002 & 1,500 \\
\hline Slides & 9-Mar-1994 & - \\
\hline Epidemic & 13-Mar-1997 & - \\
\hline Flood & 18-May-1998 & - \\
\hline Extreme Temperature & 16-Oct-2000 & - \\
\hline
\end{tabular}

Created on: 4 Jan 2006. - Data version: v06.01

Source: "EM-DAT: The OFDA/CRED International Disaster Database, www.em-dat.net - Université catholique de Louvain - Brussels - Belgium"

For some natural disasters (particularly floods and droughts) there is no exact day or month for the event, and for other disasters (particularly pre-1974) the available record of the disaster does not provide an exact day or month. 
Appendix Table 2.2

Summarized Table of Natural Disasters in Kyrgyzstan: 1992 to 2005

\begin{tabular}{|c|c|c|c|c|c|c|c|}
\hline & $\begin{array}{c}\text { \# of } \\
\text { Events }\end{array}$ & Killed & Injured & Homeless & Affected & $\begin{array}{r}\text { Total } \\
\text { Affected }\end{array}$ & $\begin{array}{r}\text { Damage US } \\
(000 \text { 's) }\end{array}$ \\
\hline Earthquake & 3 & 58 & 100 & 32,568 & 105,368 & 138,036 & 163,000 \\
\hline ave. per event & & 19 & 33 & 10,856 & 35,123 & 46,012 & 54,333 \\
\hline Epidemic & 1 & 22 & 0 & 0 & 336 & 336 & 0 \\
\hline ave. per event & & 22 & 0 & 0 & 336 & 336 & 0 \\
\hline $\begin{array}{l}\text { Extreme } \\
\text { Temperature }\end{array}$ & 1 & 11 & 0 & 0 & 0 & 0 & 0 \\
\hline ave. per event & & 11 & 0 & 0 & 0 & 0 & 0 \\
\hline Flood & 2 & 4 & 0 & 9,778 & 0 & 9,778 & 2,660 \\
\hline ave. per event & & 2 & 0 & 4,889 & 0 & 4,889 & 1,330 \\
\hline Slides & 7 & 249 & 20 & 14,155 & 45,636 & 59,811 & 37,500 \\
\hline ave. per event & & 36 & 3 & 2,022 & 6,519 & 8,544 & 5,357 \\
\hline
\end{tabular}

Created on: 4 Jan 2006. - Data version: v06.01

Source: "EM-DAT: The OFDA/CRED International Disaster Database,

www.em-dat.net - Université catholique de Louvain - Brussels - Belgium" 
Appendix Table 3.1

\section{Country Profile for Natural Disasters: Papua New Guinea}

Top 10 Natural Disasters in Papua New Guinea sorted by numbers of people killed, total affected and economic damage costs

\begin{tabular}{|l|c|c|}
\hline Disaster & Date & Killed \\
\hline Volcano & 15-Jan-1951 & 3,000 \\
\hline Wave / Surge & 17-Jul-1998 & 2,182 \\
\hline Volcano & 29-May-1937 & 506 \\
\hline Slides & 26-Feb-1991 & 200 \\
\hline Epidemic & 1-Jan-2002 & 122 \\
\hline Epidemic & 4-Feb-1998 & 114 \\
\hline Slides & 21-Mar-1971 & 100 \\
\hline Slides & 6-Sep-1988 & 76 \\
\hline Drought & 23-Sep-1997 & 60 \\
\hline Earthquake & 13-Oct-1993 & 53 \\
\hline
\end{tabular}

\begin{tabular}{|l|c|c|}
\hline Disaster & Date & Total Affected \\
\hline Drought & 23-Sep-1997 & 700,000 \\
\hline Volcano & 19-Sep-1994 & 152,002 \\
\hline Flood & Mar-1992 & 90,000 \\
\hline Flood & 12-Jun-1993 & 54,000 \\
\hline Wind Storm & 14-May-1993 & 40,040 \\
\hline Drought & Mar-1981 & 40,000 \\
\hline Flood & 23-Apr-1999 & 38,000 \\
\hline Volcano & 15-Oct-1983 & 25,000 \\
\hline Earthquake & 13-Oct-1993 & 20,200 \\
\hline Volcano & 2-Jun-2005 & 15,000 \\
\hline
\end{tabular}

\begin{tabular}{|l|c|c|}
\hline \hline Disaster & Date & Damage US\$ (000's) \\
\hline Volcano & 19-Sep-1994 & 400,000 \\
\hline Flood & 23-Apr-1999 & 43,228 \\
\hline Flood & Sep-1983 & 11,900 \\
\hline Earthquake & 13-Oct-1993 & 5,000 \\
\hline Earthquake & 9-Feb-1987 & 2,625 \\
\hline Flood & 12-Jun-1993 & 2,500 \\
\hline Earthquake & 31-Oct-1970 & 1,750 \\
\hline Wind Storm & 14-May-1993 & 1,500 \\
\hline Earthquake & 11-May-1985 & 1,000 \\
\hline Earthquake & 24-Jun-1986 & 500 \\
\hline
\end{tabular}

Created on: 4 Jan 2006. - Data version: v06.01

Source: "EM-DAT: The OFDA/CRED International Disaster Database,

www.em-dat.net - Université catholique de Louvain - Brussels - Belgium"

For some natural disasters (particularly floods and droughts) there is no exact day or month for the event, and for other disasters (particularly pre-1974) the available record of the disaster does not provide an exact day or month. 
Appendix Table 3.2: Summarized Table of natural Disasters in Papua New Guinea: 1930 to 2005

\begin{tabular}{|c|c|c|c|c|c|c|c|}
\hline & $\begin{array}{l}\text { \# of } \\
\text { Events }\end{array}$ & Killed & Injured & Homeless & Affected & $\begin{array}{r}\text { Total } \\
\text { Affected }\end{array}$ & $\begin{array}{r}\text { DamageUS } \\
(000 \text { 's }\end{array}$ \\
\hline Drought & 3 & 88 & 0 & 0 & 746,000 & 746,000 & 0 \\
\hline ave. per event & & 29 & 0 & 0 & 248,667 & 248,667 & 0 \\
\hline Earthquake & 12 & 86 & 271 & 16,400 & 19,400 & 36,071 & 10,875 \\
\hline ave. per event & & 7 & 23 & 1,367 & 1,617 & 3,006 & 906 \\
\hline Epidemic & 4 & 256 & 0 & 0 & 3,610 & 3,610 & 0 \\
\hline ave. per event & & 64 & 0 & 0 & 903 & 903 & 0 \\
\hline Famine & 1 & 0 & 0 & 0 & 0 & 0 & 0 \\
\hline ave. per event & & 0 & 0 & 0 & 0 & 0 & 0 \\
\hline Flood & 7 & 59 & 0 & 78,000 & 127,000 & 205,000 & 57,628 \\
\hline ave. per event & & 8 & 0 & 11,143 & 18,143 & 29,286 & 8,233 \\
\hline Slides & 8 & 476 & 40 & 5,000 & 1,763 & 6,803 & 0 \\
\hline ave. per event & & 60 & 5 & 625 & 220 & 850 & 0 \\
\hline Volcano & 12 & 3,515 & 31 & 46,000 & 183,100 & 229,131 & 400,000 \\
\hline ave. per event & & 293 & 3 & 3,833 & 15,258 & 19,094 & 33,333 \\
\hline Wave / Surge & 2 & 2,193 & 668 & 0 & 9,199 & 9,867 & 0 \\
\hline ave. per event & & 1,097 & 334 & 0 & 4,600 & 4,934 & 0 \\
\hline Wild Fires & 1 & 0 & 0 & 0 & 8,000 & 8,000 & 0 \\
\hline ave. per event & & 0 & 0 & 0 & 8,000 & 8,000 & 0 \\
\hline Wind Storm & 3 & 47 & 40 & 22,500 & 25,000 & 47,540 & 1,500 \\
\hline ave. per event & & 16 & 13 & 7,500 & 8,333 & 15,847 & 500 \\
\hline
\end{tabular}

Created on: 4 Jan 2006. - Data version: v06.01

Source: "EM-DAT: The OFDA/CRED International Disaster Database,

www.em-dat.net - Université catholique de Louvain - Brussels - Belgium"

*Events recorded in the CRED EM-DAT. First Event: 1930, Last Entry: Aug 2005.

*Epidemics included: Respiratory(Acute respiratory syndrome), Measles, 


\section{Appendix Table 4.1}

\section{Country Profile for Natural Disasters: Vanuatu}

Top 10 Natural Disasters in Vanuatu sorted by numbers of people killed, total affected and economic damage

\begin{tabular}{|l|c|c|}
\hline \hline Disaster & Date & Killed \\
\hline Wind Storm & 24-Dec-1951 & 100 \\
\hline Wind Storm & 7-Feb-1987 & 48 \\
\hline Wind Storm & 8-May-1999 & 32 \\
\hline Earthquake & 27-Nov-1999 & 12 \\
\hline Wind Storm & 16-Jan-1985 & 9 \\
\hline Wind Storm & 2-Feb-1972 & 4 \\
\hline Wind Storm & 30-Mar-1993 & 4 \\
\hline Wind Storm & 9-Jan-1992 & 2 \\
\hline Wind Storm & 25-Feb-2004 & 2 \\
\hline Slides & 1988 & 1 \\
\hline
\end{tabular}

\begin{tabular}{|l|c|c|}
\hline Disaster & Date & Total Affected \\
\hline Wind Storm & 16-Jan-1985 & 117,500 \\
\hline Wind Storm & 25-Feb-2004 & 54,008 \\
\hline Wind Storm & 7-Feb-1987 & 48,000 \\
\hline Earthquake & 27-Nov-1999 & 14,100 \\
\hline Wind Storm & 30-Mar-1993 & 12,005 \\
\hline Volcano & 27-Nov-2005 & 5,000 \\
\hline Wind Storm & 11-Jan-1988 & 4,700 \\
\hline Volcano & 8-Jun-2001 & 4,500 \\
\hline Flood & 21-Dec-2002 & 3,001 \\
\hline Slides & 1988 & 3,000 \\
\hline
\end{tabular}

\begin{tabular}{|l|c|c|}
\hline Disaster & Date & Damage US\$ (000's) \\
\hline Wind Storm & 16-Jan-1985 & 173,000 \\
\hline Wind Storm & 7-Feb-1987 & 25,000 \\
\hline Wind Storm & 30-Mar-1993 & 6,000 \\
\hline Wind Storm & 12-Dec-1981 & 1,000 \\
\hline Wind Storm & 24-Dec-1951 & 250 \\
\hline Wind Storm & 8-Feb-1940 & - \\
\hline Wind Storm & 28-Dec-1959 & - \\
\hline Wind Storm & 18-Jan-1972 & - \\
\hline Wind Storm & 2-Feb-1972 & - \\
\hline Wind Storm & 17-Apr-1972 & \\
\hline
\end{tabular}

Created on: 4 Jan 2006. - Data version: v06.01

Source: "EM-DAT: The OFDA/CRED International Disaster Database, www.em-dat.net - Université catholique de Louvain - Brussels - Belgium"

For some natural disasters (particularly floods and droughts) there is no exact day or month for the event, and for other disasters (particularly pre-1974) the available record of the disaster does not provide an exact day or month. 


\section{Appendix Table 4.2}

Summarized Table of Natural Disasters in Vanuatu: 1940 to 2005

\begin{tabular}{|c|c|c|c|c|c|c|c|}
\hline & $\begin{array}{c}\text { \# of } \\
\text { Events }\end{array}$ & Killed & Injured & Homeless & Affected & $\begin{array}{r}\text { Total } \\
\text { Affected }\end{array}$ & $\begin{array}{r}\text { Damage US } \\
(000 \text { 's })\end{array}$ \\
\hline Earthquake & 8 & 12 & 105 & 2,000 & 13,000 & 15,105 & 0 \\
\hline ave. per event & & 2 & 13 & 250 & 1,625 & 1,888 & 0 \\
\hline Flood & 1 & 0 & 1 & 0 & 3,000 & 3,001 & 0 \\
\hline ave. per event & & 0 & 1 & 0 & 3,000 & 3,001 & 0 \\
\hline Slides & 1 & 1 & 0 & 3,000 & 0 & 3,000 & 0 \\
\hline ave. per event & & 1 & 0 & 3,000 & 0 & 3,000 & 0 \\
\hline Volcano & 2 & 0 & 0 & 0 & 9,500 & 9,500 & 0 \\
\hline ave. per event & & 0 & 0 & 0 & 4,750 & 4,750 & 0 \\
\hline Wind Storm & 23 & 203 & 23 & 10,895 & 231,655 & 242,573 & 205,250 \\
\hline ave. per event & & 9 & 1 & 474 & 10,072 & 10,547 & 8,924 \\
\hline
\end{tabular}

Source: "EM-DAT: The OFDA/CRED International Disaster Database, www.em-dat.net - Université catholique de Louvain - Brussels - Belgium

*Events recorded in the CRED EM-DAT. First Event: Feb/1940, Last Entry: Nov/2005.

*Epidemics included: 